\title{
EFIKASI BEBERAPA SEDIAAN VAKSIN Streptococcus agalactiae-N14G UNTUK PENCEGAHAN PENYAKIT STREPTOCOCCOSIS PADA IKAN NILA, Oreochromis niloticus
}

\author{
Taukhid, Uni Purwaningsih, dan Angela Mariana Lusiastuti \\ Balai Penelitian dan Pengembangan Budidaya Air Tawar \\ Jl. Sempur No. 1, Bogor 16154 \\ E-mail: taukhid_as@yahoo.co.id; Iusiastuti_61@yahoo.co.id
}

(Naskah diterima: 19 Maret 2014; Disetujui publikasi: 7 Juli 2014)

\begin{abstract}
ABSTRAK
Penelitian dengan tujuan untuk mengetahui efikasi berbagai sediaan (biakan cair, sel utuh, supernatan dengan dan tanpa penyaringan) vaksin Streptococcus agalactiaeN14G untuk pencegahan penyakit Streptococcosis pada ikan nila telah dilakukan pada skala laboratorium. Isolat bakteri Streptococcus agalactiae-N14G digunakan sebagai sumber antigen dalam pembuatan vaksin. Ikan nila dengan rata-rata ukuran 10-15 g/ekor dan diasumsikan bebas penyakit infeksi Streptococcus agalactiae (specific pathogen free, SPF) terhadap patogen target digunakan sebagai ikan uji. Pada hari ke-14 pasca vaksinasi, dilakukan uji tantang dengan bakteri homolog aktif pada dosis lethal $\left(\mathrm{LD}_{50}\right)$, dan pengamatan dilakukan selama 21 hari. Hasil penelitian menunjukkan efikasi sediaan vaksin tertinggi diperoleh pada sediaan vaksin sel utuh (B) $(76,0 \%)$, selanjutnya diikuti oleh sediaan vaksin biakan cair (A) $(65,0 \%)$, sediaan vaksin supernatan tanpa penyaringan (C) $(49,0 \%)$, dan sediaan vaksin dengan penyaringan (D) (36,0\%); sedangkan pada kelompok kontrol positif dan negatif, masingmasing sebesar $25,0 \%$ dan $34,0 \%$. Dua jenis sediaan vaksin masuk kategori efektif dengan nilai relative percentage survival (RPS) $850 \%$, yaitu jenis vaksin sel utuh $(68,00 \%)$ dan jenis sediaan vaksin biakan cair $(53,37 \%)$.
\end{abstract}

KATA KUNCl: efikasi, vaksin, Streptococcosis, ikan nila

ABSTRACT: Efficacy of different preparations of Streptococcus agalactiae vaccine to prevent Streptococcosis on tilapia, Oreochromis niloticus. By: Taukhid, Uni Purwaningsih, and Angela Mariana Lusiastuti

The research with the aim to know an efficacious of different preparations ( $A$. broth, B. whole cell, C. crude extra cellular product, D. pure extra cellular product), and control group (positive and negative) of Streptococcus agalactiae vaccine to prevent Streptococcosis on tilapia has been carried out at laboratory level. S. agalactiae isolate code number of NI4G was used as a master seed on vaccine production. Challenge test against homolog bacteria at the lethal dose $\left(L D_{50}\right)$ was done at $14^{\text {th }}$ days post vaccination for 21 days observation. The results showed that the efficacious vaccine preparation was evaluated by survival rate indicators were: whole cell vaccine (B) (76.0\%), followed by broth vaccine (A) (65.0\%), crude extra cellular product (C) (49.0\%), and pure extra cellular product vaccine (D) (36.0\%). Survival rate of positive control was $25.0 \%$, and $34.0 \%$ for negative control. Two types of vaccine preparation 
showed effective grade based on relative percentage survival (RPS) value, namely whole cell vaccine (68.00\%), and broth vaccine (53.37\%).

\section{KEYWORDS: eficative, vaccine, Streptococcosis, tilapia}

\section{PENDAHULUAN}

Ikan nila dikenal sebagai jenis ikan budidaya yang cepat tumbuh, teknik budidayanya relatif mudah, memiliki toleransi yang luas terhadap variasi kondisi lingkungan budidaya, serta relatif tahan terhadap gangguan penyakit. Sejalan dengan perkembangan budidaya ikan nila yang makin intensif, masalah penyakit telah menjadi salah satu kendala dan harus menjadi perhatian serius dalam pengembangan budidaya ikan nila di Indonesia.

Streptococcosis merupakan penyakit infeksius yang semakin sering terjadi pada budidaya ikan nila. Taukhid \& Purwaningsih (2009) menyatakan bahwa kasus Streptococcosis pada ikan nila di beberapa sentra-sentra budidaya ikan nila di Jawa Barat dan Jawa Tengah umumnya disebabkan oleh infeksi bakteri S. agalactiae (85\%) dan S. iniae (15\%).

Infeksi Streptococcus spp. pada ikan mengakibatkan penyakit yang disebut "syndrome meningoencephalitis dan panophthalmitis" dengan gejala umum seperti: lemah, warna gelap, hilang nafsu makan, disorientasi atau hilang keseimbangan, uni/bilateral exophthalmia dengan kornea mata berwarna pucat, pendarahan pada bagian eksternal, serta luka. Pada organ internal menunjukkan gejala adanya ascites, pembengkakan limfa, ginjal, hati, dan organ dalam lainnya (Plumb, 1975). Kasus Streptococcosis pada ikan nila dengan kematian yang tinggi umumnya terkait dengan multi faktor seperti fluktuasi suhu air, peningkatan kadar ammonia dan kadar oksigen terlarut yang rendah (Evans et al., 2002).

Selama ini, teknik pengendalian penyakit pada perikanan budidaya lebih mengandalkan pada penggunaan bahan kimia/obat/ antibiotik. Terkait dengan penggunaan bahan kimia/obat/antibiotik dalam proses produksi perikanan, pemerintah telah mengeluarkan regulasi yang tegas.

Teknologi pengendalian penyakit ikan melalui pendekatan biologis seperti vaksinasi, pemanfaatan mikroba esensial, serta terapi herbal merupakan opsi solusi yang sangat realistis, prospektif, aplikatif, dan ramah lingkungan.
Pencegahan merupakan langkah paling ideal untuk pengendalian penyakit pada perikanan budidaya. Strategi pencegahan penyakit secara dini yang sudah diyakini cukup efektif adalah melalui vaksinasi. Vaksinasi pada perikanan budidaya telah terbukti memberi kontribusi yang sangat signifikan terhadap peningkatan produksi perikanan budidaya, terutama industri salmon dan trout di Eropa.

Vaksin untuk pencegahan Streptococcosis pada ikan telah dieksplorasi, antara lain oleh Eldar et al. (1995) terhadap infeksi S. difficile, Akhlaghi et al. (1996) terhadap infeksi Streptococcus sp., terhadap S. iniae oleh Eldar et al. (1997), serta Klesius et al. (2000), dan Evans et al. (2004a, 2004b, dan 2004c) yang mengevaluasi efikasi dari vaksin inaktif yang mengandung extracellular products (ECP) dan formalin-killed sel utuh S. agalactiae. Taukhid \& Purwaningsih (2009) menyatakan bahwa pemberian vaksin whole cell yang diinaktivasi dengan menggunakan formalin memberikan titer antibodi dan sintasan ikan uji yang lebih baik, dibandingkan dengan proses inaktivasi melalui pemanasan maupun sonikasi. Sedangkan Pasnik et al. (2005) menyatakan bahwa pemberian vaksin ECP S. agalactiae pada ikan nila memberikan perlindungan terhadap infeksi bakteri homolog hingga 180 hari pasca pemberian vaksin.

Penelitian ini bertujuan untuk mengetahui efikasi berbagai sediaan vaksin Streptococcus agalactiae-N14G (biakan cair, sel utuh, supernatan dengan dan tanpa penyaringan) untuk pencegahan penyakit Streptococcosis pada ikan nila.

\section{BAHAN DAN METODE}

Penelitian ini dilakukan pada skala laboratorium, prosedur pelaksanaan kegiatan meIalui tahapan sebagai berikut:

\section{Ikan Uji}

Ikan uji yang digunakan adalah ikan nila sebagai inang rentan (susceptible host) terhadap infeksi S. agalactiae dengan ukuran $\pm 15 \mathrm{~g}$ /ekor. Ikan uji berasal dari populasi ho- 
mogen dan diasumsikan "specific pathogen free (SPF)" terhadap patogen target berdasarkan hasil diagnosa secara bakteriologis yang dilakukan secara acak terhadap populasi tersebut sebelum proses aklimatisasi.

Pemberian pakan dilakukan secara adlibitum sebanyak 3 kali/hari (pagi, siang, dan sore). Jenis pakan yang digunakan adalah pakan komersial (pelet apung) dengan kadar protein kasar sebesar $\pm 20 \%$.

\section{Aktivasi Bakteri untuk Sediaan Vaksin S. agalactiae-N14G}

Sediaan bakteri S. agalactiae-N14G yang dibiakkan pada media cair (BHI + gliserol) dan disimpan pada suhu $-20^{\circ} \mathrm{C}$, ditumbuhkan kembali pada media BHIB. Selanjutnya, prosedur Koch's postulate dilakukan dengan menyuntikan $0,1 \mathrm{~mL}$ inokulum ke ikan nila uji secara intraperitonial (IP). Reisolasi dilakukan terhadap individu ikan uji yang menunjukkan gejala klinis, selanjutnya isolat bakteri tersebut direkarakterisasi (SNI 7545.3:2009) yang meliputi: pengujian pewarnaan gram, motilitas, oksidase, oksidatif-fermentatif, katalase, penumbuhan dalam bile salt $40 \%$, penumbuhan dalam $\mathrm{NaCl} 6,5 \%$, hemolisis darah, aesculin hydrolysis, dan asam D-mannitol.

\section{Pengujian Efikasi}

Pengujian efikasi masing-masing sediaan vaksin dilakukan melalui penyuntikan terhadap ikan nila uji pada dosis yang diasumsikan relatif sama. Perlakuan yang diterapkan adalah pemberian lima macam sediaan vaksin dengan ulangan sebanyak tiga kali. Rancangan percobaan yang digunakan adalah rancangan acak lengkap (RAL). Kelima macam sediaan vaksin tersebut adalah, $A$ : vaksin biakan cair (Broth vaccine) kepadatan $10^{8} \mathrm{cfu} /$ $\mathrm{mL}$; $\mathrm{B}$ : vaksin sel utuh (whole cells vaccine) kepadatan $10^{8} \mathrm{cfu} / \mathrm{mL}$; C: supernatan tanpa penyaringan (crude ECP) dari biakan baku $10^{8}$ $\mathrm{cfu} / \mathrm{mL}$; D: supernatan dengan penyaringan (pure ECP) dari biakan baku $10^{8} \mathrm{cfu} / \mathrm{mL}$; E: kontrol positif, larutan phosphate buffer saline (PBS); F: kontrol negatif, tanpa pemberian materi apapun.

\section{Penyiapan Sediaan Vaksin}

Vaksin disiapkan dengan cara membiakkan bakteri S. agalactiae terpilih pada media BHIB dan diinkubasi dalam inkubator pada suhu $29^{\circ} \mathrm{C}$ selama 24 jam. Proses inaktivasi dilaku- kan dengan menambahkan formalin (formalin killed) sebanyak $1 \%(\mathrm{v} / \mathrm{v})$ pada biakan baku. Pengujian viabilitas dilakukan 24 jam pasca proses inaktivasi untuk mengetahui bahwa sediaan vaksin sudah benar-benar inaktif.

Uji viabilitas dilakukan dengan cara menumbuhkan sediaan vaksin yang telah diinaktivasi dengan larutan formalin $1 \%$ pada media BHIA, dan diinkubasi pada suhu $29^{\circ} \mathrm{C}$ selama 24-72 jam. Apabila tidak ada pertumbuhan bakteri pada medium BHIA selama 72 jam pengamatan, maka sediaan vaksin tersebut sudah inaktif. Sediaan biakan cair yang telah memenuhi persyaratan, selanjutnya digunakan sebagai sediaan vaksin biakan cair.

Penyiapan sediaan vaksin sel utuh dilakukan melalui sentrifugasi sebanyak dua kali pada $7.000 \mathrm{rpm}$, masing-masing selama 30 menit pada suhu $4^{\circ} \mathrm{C}$. Supernatan kemudian dibuang, endapan (pellet) dicuci dengan larutan phosphat buffer saline (PBS) steril. Pellet yang didapat, disuspensikan ke dalam larutan PBS steril hingga mencapai volume awal, sehingga sediaan vaksin sel utuh tersebut diasumsikan memiliki konsentrasi yang sama dengan sediaan vaksin biakan cair.

Penyiapan sediaan vaksin supernatan tanpa penyaringan dilakukan dengan mensentrifus sediaan vaksin biakan cair pada $7.000 \mathrm{rpm}$ selama 30 menit pada suhu $4^{\circ} \mathrm{C}$. Fraksi cair/ supernatan hasil proses sentrifus tersebut diambil, dan digunakan sebagai sediaan vaksin supernatan tanpa penyaringan, sedangkan sisa endapan atau fraksi pellet dibuang.

Penyiapan sediaan vaksin supernatan dengan penyaringan dilakukan melalui penyaringan larutan vaksin biakan cair yang tidak diinaktivasi, disentrifus dengan kecepatan $7.000 \mathrm{rpm}$ selama 30 menit pada suhu $4^{\circ} \mathrm{C}$. Fraksi cair dari proses pemusingan tersebut diambil, dan disaring dengan milipore filter $0,45 \mu \mathrm{M}$. Hasil penyaringan tersebut digunakan sebagai sediaan vaksin supernatan dengan penyaringan.

\section{Vaksinasi}

Vaksin yang telah dipersiapkan dalam beberapa sediaan, diberikan ke ikan uji melalui penyuntikan masing-masing sebanyak $0,1 \mathrm{~mL} /$ ekor secara intraperitoneal (IP). Rata-rata bobot ikan uji berkisar antara 10-15 g/ekor, dan jumlah ikan untuk setiap kelompok perlakuan adalah 200 ekor. Ikan yang telah divaksin, selanjutnya dipelihara dalam bak fiber glass 
volume $200 \mathrm{~L}$ selama 14 hari secara pooling sesuai dengan kelompok perlakuan yang diberikan.

Selama masa vaksinasi, ikan uji diberi pakan dengan frekuensi tiga kali sehari yakni pada pagi (08.00), siang (12.00), dan sore hari (16.00) sebanyak 3\%-5\% dari bobot biomassa. Penyiponan dan penggantian air baru dilakukan setiap hari untuk membuang sisa pakan dan sisa metabolisme.

\section{Uji Tantang}

Pada hari ke-14 pasca pemberian vaksin, masing-masing kelompok perlakuan dilakukan uji tantang terhadap homolog bakteri aktif. Uji tantang secara eksperimental, dilakukan dalam akuarium ukuran $30 \mathrm{~cm} \times 40 \mathrm{~cm} \times 35 \mathrm{~cm}$ diisi air sebanyak $40 \mathrm{~L}$ dengan kepadatan 15 ekor/wadah. Masing-masing kelompok perlakuan dilakukan pengulangan sebanyak tiga kali. Uji tantang dilakukan melalui teknik penyuntikan bakteri aktif secara IP pada dosis $\mathrm{LD}_{50}$, dan pengamatan dilakukan selama 21 hari.

Pengamatan terhadap tingkah laku, gejala klinis, dan mortalitas ikan uji dilakukan setiap hari hingga akhir periode pengujian. Efektivitas vaksin dievaluasi berdasarkan pendekatan nilai titer antibodi dengan teknik direct agglutination test. Level proteksi relatif diukur melalui uji tantang ikan uji terhadap patogen target pada dosis letal $\left(\mathrm{LD}_{50}\right)$, untuk selanjutnya dihitung nilai mortalitas kumulatif, survival rate (SR), serta relative percentage survival (RPS) selama proses pengujian. Penentuan nilai $L_{50}$ dari isolat bakteri yang digunakan pada pengujian ini didasarkan pada nilai $\mathrm{LD}_{50}$ dari hasil penelitian yang dilakukan oleh Taukhid \& Purwaningsih (2009) dengan nilai matematis $Y=15,4062+10,4127 \mathrm{X}$ atau setara dengan $2,1 \times 10^{3} \mathrm{cfu} / \mathrm{mL}$.

Evaluasi keamanan vaksin (vaccine safety) dihitung melalui ada tidaknya kematian pasca vaksinasi yang dihitung berdasarkan jumlah kematian yang terjadi secara akut selama 24 jam pada kelompok ikan yang divaksin dibandingkan dengan kelompok ikan kontrol.

\section{Analisis Data}

Data sintasan dianalisis menggunakan sidik ragam (Anova) untuk mengetahui pengaruh perlakuan yang diterapkan. Sebelum dianalisis, data terlebih dahulu diuji dengan uji homogenitas, uji normalitas, dan uji aditifitas.
Analisis dilakukan menggunakan program statistical analysis system (SAS) dengan program general linear model (GLM), jika hasil analisis diperoleh beda nyata $(P<0,05)$ atau sangat beda nyata $(P<0,01)$ maka dilanjutkan dengan uji Duncan untuk melihat perbedaan dari masing-masing dan untuk mengetahui interaksi antar perlakuan.

\section{HASIL DAN BAHASAN}

\section{Hasil}

Hasil pemeriksaan secara bakteriologis, tidak ditemukan adanya infeksi bakteri Streptococcus spp. pada seluruh sampel yang diisolasi. Berdasarkan hasil pemeriksaan awal tersebut, maka dapat diasumsikan bahwa populasi ikan nila yang digunakan pada penelitian ini adalah populasi bebas penyakit infeksi S. agalactiae.

Hasil karakterisasi secara biokimia menurut metode Standar Nasional Indonesia (SNI 7545.3:2009) "Metode identifikasi bakteri Streptococcus iniae dan S. agalactiae pada ikan secara konvensional", serta API 20 STREP System terhadap isolat bakteri S. agalactiae yang digunakan sebagai sediaan bakteri untuk pembuatan vaksin selengkapnya disajikan pada Tabel 1. Berdasarkan hasil uji bakteriologi, maka secara definitif bahwa jenis bakteri yang digunakan pada penelitian ini adalah $S$. agalactiae.

Preparasi sediaan larutan baku vaksin yang dilakukan pada penelitian ini mengacu pada teknik pembuatan yang dilakukan oleh Taukhid \& Purwaningsih (2009).

Nilai titer antibodi pada serum darah ikan uji untuk masing-masing kelompok perlakuan memperlihatkan bahwa fluktuasi nilai titer antibodi pada masing-masing kelompok perlakuan sangat variatif, baik terhadap nilai ratarata persentase sintasan maupun periode pengamatan. Nilai-nilai tersebut selengkapnya dapat dilihat pada Tabel 2. Pada Tabel 2 menunjukkan bahwa nilai titer antibodi yang tinggi hingga pengenceran ke-256 dan terdeteksi pada kelompok perlakuan D (vaksin ECP dengan penyaringan) pada minggu ke-4, dan pada kelompok perlakuan B (vaksin sel utuh) pada minggu ke-5 dan 7 .

Uji tantang dengan cara infeksi buatan dengan bakteri homolog pada hari ke-14 pasca pemberian vaksin dilakukan melalui penyuntikan secara intra peritoneal pada dosis le- 
Tabel 1. Hasil karakterisasi uji-biokimia isolat bakteri Streptococcus agalactiae-N14G yang diisolasi dari hasil Koch's Postulate kedua, dan digunakan sebagai master seed pembuatan vaksin

Table 1. Biochemical test of Streptococcus agalactiae-N14G from Koch's Postulate which used as master seed of vaccine

\begin{tabular}{lc}
\hline \multicolumn{1}{c}{ Uji (Test) } & Karakter (Character) \\
\hline Bentuk (Form) & Kokus (Coccus) \\
Gram & Positif (Positive) \\
Motilitas (Motility) & Non motile \\
Oksidase & Negatif (Negative) \\
Oksidative/Fermentative & Fermentative \\
Katalase & Negatif (Negative) \\
Bile salt 40\% & Positif (Tumbuh setelah 48 jam) \\
Tumbuh pada NaCl 6,5\% & Positive (Growafter 48 hours) \\
Growth at $\mathrm{NaCl} \mathrm{6.5 \%}$ & Positif (Tumbuh setelah 24 jam) \\
Aesculin hydrolysis & Positive (Growafter 24 hours) \\
Asam D-manitol & Negatif (Pengamatan 48 jam) \\
Haemolysis & Negative (Observation at 48 hours) \\
Negatif (Pengamatan 48 jam)
\end{tabular}
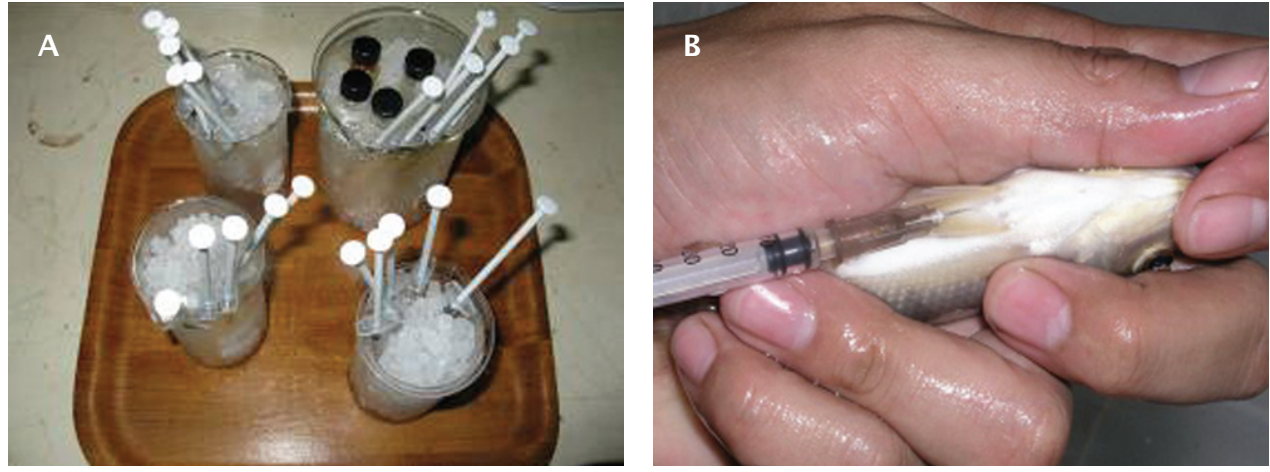

Gambar 1. Beberapa sediaan vaksin Streptococcus agalactiae-N14G yang siap untuk digunakan untuk vaksinasi (A) dan pemberian vaksin ke ikan uji melalui teknik penyuntikan secara intra peritoneal (B)

Figure 1. Several kind of vaccine of Streptococcus agalactiae-N14G which ready to use (A) and vaccine application via intra peritoneal injection (B)

thal $\left(\mathrm{LD}_{50}\right)$ (Gambar 1). Setelah 24 jam pasca pemberian infeksi buatan, terlihat adanya perubahan tingkah laku dan mulai muncul gejala klinis seperti lemah, warna gelap, hilang nafsu makan, disorientasi atau hilang keseimbangan. Pada hari ke-3 hingga hari ke-7 mulai terlihat adanya gejala uni/bilateral exophthalmia dengan kornea mata berwarna pucat, pendarahan pada bagian eksternal, luka, dan pada organ internal menunjukkan gejala adanya ascites, pembengkakan limfa, ginjal, hati, dan organ dalam lainnya. Kematian ikan uji pada masing-masing kelompok perlakuan mulai terjadi 24 jam pasca pemberian infeksi buatan, 
Tabel 2. Nilai titer antibodi serum darah ikan uji selama proses induksi kekebalan spesifik terhadap Streptococcus agalactiae

Table 2. Serum antibody titer value of fish test inspesific immunity induction against Streptococcus agalactiae

\begin{tabular}{|c|c|c|c|c|c|c|c|c|c|c|c|}
\hline \multirow{2}{*}{ Sampling } & \multirow{2}{*}{$\begin{array}{l}\text { Perlakuan } \\
\text { Treatments }\end{array}$} & \multicolumn{10}{|c|}{ Pengenceran (Dilution) } \\
\hline & & 0 & 2 & 4 & 8 & 16 & 32 & 64 & 128 & 256 & 512 \\
\hline Minggu (Week) 0 & Pooled & + & + & \pm & - & - & - & - & - & - & - \\
\hline Minggu I & A & + & + & + & + & \pm & - & - & - & - & - \\
\hline \multirow[t]{5}{*}{ Week 1} & B & + & + & + & + & + & \pm & - & - & - & - \\
\hline & $\mathrm{C}$ & \pm & - & - & - & - & - & - & - & - & - \\
\hline & $\mathrm{D}$ & + & + & + & \pm & - & - & - & - & - & - \\
\hline & $\mathrm{E}$ & \pm & - & - & - & - & - & - & - & - & - \\
\hline & $\mathrm{F}$ & - & - & - & - & - & - & - & - & - & - \\
\hline \multirow{6}{*}{$\begin{array}{l}\text { Minggu II } \\
\text { Week } 2\end{array}$} & $A$ & \pm & - & - & - & - & - & - & - & - & - \\
\hline & B & + & + & \pm & - & - & - & - & - & - & - \\
\hline & C & \pm & - & - & - & - & - & - & - & - & - \\
\hline & $\mathrm{D}$ & + & \pm & - & - & - & - & - & - & - & - \\
\hline & $E$ & \pm & - & - & - & - & - & - & - & - & - \\
\hline & $F$ & - & - & - & - & - & - & - & - & - & - \\
\hline \multirow{6}{*}{$\begin{array}{l}\text { Minggu III } \\
\text { Week } 3\end{array}$} & $A$ & + & + & \pm & - & - & - & - & - & - & - \\
\hline & B & + & + & + & + & + & + & \pm & - & - & - \\
\hline & C & + & + & + & \pm & - & - & - & - & - & - \\
\hline & D & + & + & + & + & + & + & + & + & \pm & - \\
\hline & $\mathrm{E}$ & + & \pm & - & - & - & - & - & - & - & - \\
\hline & $\mathrm{F}$ & - & - & - & - & - & - & - & - & - & - \\
\hline \multirow{6}{*}{$\begin{array}{l}\text { Minggu IV } \\
\text { Week } 4\end{array}$} & $A$ & + & + & + & + & + & + & + & \pm & - & - \\
\hline & B & + & + & + & + & + & + & + & + & \pm & - \\
\hline & C & + & + & + & \pm & - & - & - & - & - & - \\
\hline & D & + & + & + & + & + & \pm & - & - & - & - \\
\hline & $\mathrm{E}$ & + & \pm & - & - & - & - & - & - & - & - \\
\hline & $\mathrm{F}$ & \pm & - & - & - & - & - & - & - & - & - \\
\hline \multirow{6}{*}{$\begin{array}{l}\text { Minggu V } \\
\text { Week } 5\end{array}$} & $A$ & + & + & \pm & - & - & - & - & - & - & - \\
\hline & B & + & + & + & + & + & + & \pm & - & - & - \\
\hline & C & + & + & + & \pm & - & - & - & - & - & - \\
\hline & $D$ & + & + & + & + & \pm & - & - & - & - & - \\
\hline & $\mathrm{E}$ & + & \pm & - & - & - & - & - & - & - & - \\
\hline & $\mathrm{F}$ & \pm & - & - & - & - & - & - & - & - & - \\
\hline \multirow{6}{*}{$\begin{array}{l}\text { Minggu VI } \\
\text { Week } 6\end{array}$} & $A$ & + & + & + & + & + & + & + & \pm & - & - \\
\hline & B & + & + & + & + & + & + & + & + & \pm & - \\
\hline & $C$ & + & + & + & \pm & - & - & - & - & - & - \\
\hline & D & + & + & + & + & + & \pm & - & - & - & - \\
\hline & $\mathrm{E}$ & + & + & \pm & - & - & - & - & - & - & - \\
\hline & $F$ & \pm & - & - & - & - & - & - & - & - & - \\
\hline
\end{tabular}


Lanjutan Tabel 2 (Table 2 continued)

\begin{tabular}{lccccccccccccc}
\hline \multirow{2}{*}{ Sampling } & \multirow{2}{*}{$\begin{array}{c}\text { Perlakuan } \\
\text { Treatments }\end{array}$} & \multicolumn{1}{c}{ Pengenceran (Dilution) } \\
\cline { 3 - 12 } & & 0 & 2 & 4 & 8 & 16 & 32 & 64 & 128 & 256 & 512 \\
\hline Minggu VII & A & + & + & + & + & \pm & - & - & - & - & - \\
Week 7 & B & + & + & + & \pm & - & - & - & - & - & - \\
& C & + & + & + & + & \pm & - & - & - & - & - \\
& D & + & + & \pm & - & - & - & - & - & - & - \\
& E & + & \pm & - & - & - & - & - & - & - & - \\
& F & \pm & - & - & - & - & - & - & - & - & - \\
\hline
\end{tabular}

Keterangan (Remarks):

$\mathrm{A}=$ Vaksin biakan cair, $\mathrm{B}=$ Vaksin sel utuh, $\mathrm{C}=$ Vaksin ECP tanpa penyaringan, $\mathrm{D}=$ Vaksin ECP dengan penyaringan, $\mathrm{E}=$ Kontrol positif dengan phosphate buffered saline (PBS), $\mathrm{F}=$ Kontrol negatif, tanpa perlakuan $(A=$ Broth vaccine, $B=$ Whole cell vaccine, $C=$ Crude $E C P$ vaccine, $D=P$ Pre $E C P$ vaccine, $E=$ Positive control phosphate buffered saline (PBS), $F=$ Negative control, without treatment)

dan rata-rata mortalitas tertinggi mulai terjadi pada hari ke-5 hingga hari ke-11.

Reisolasi bakteri dari sampel ikan uji yang sedang sekarat (moribund fish) dari masingmasing kelompok perlakuan menunjukkan bahwa dari organ mata dan otak ditemukan bakteri S. agalactiae dengan prevalensi 100\%; sedangkan dari organ ginjal dan hati diperoleh nilai prevalensi masing-masing sebesar $70 \%$ dan 60\%. Berdasarkan hasil tersebut, maka dapat dipastikan bahwa kematian selama proses uji tantang yang terjadi pada ikan nila uji disebabkan oleh infeksi bakteri S. agalactiae yang diinfeksikan secara buatan.

Rata-rata nilai persentase sintasan pasca uji tantang yang diamati selama tiga minggu terhadap isolat bakteri homolog (S. agalactiaeN14G) menunjukkan bahwa secara umum pemberian sediaan vaksin sel utuh (B) memberikan nilai sintasan tertinggi yaitu sebesar 76,0\%; selanjutnya diikuti oleh kelompok perlakuan sediaan vaksin biakan cair (A) sebesar $65,0 \%$; sediaan vaksin supernatan tanpa penyaringan (C) sebesar $49,0 \%$ dan sediaan vaksin dengan penyaringan (D) sebesar $36,0 \%$. Sedangkan pada kelompok kontrol positif dan negatif, masing-masing sebesar $25,0 \%$ dan $34,0 \%$. Nilai rata-rata persentase sintasan kumulatif setiap minggu hingga akhir periode pengamatan dari masing-masing kelompok perlakuan selengkapnya disajikan pada Tabel 3.

Selain indikator nilai rata-rata persentase sintasan, efektivitas suatu jenis vaksin juga dapat dievaluasi berdasarkan nilai relative percent survival (RPS) yang merupakan nilai persentase relatif sintasan kelompok ikan yang divaksin dibandingkan dengan nilai parameter yang sama dari kelompok ikan kontrol. Nilai RPS ikan uji pada akhir pengujian dari masing-masing kelompok perlakuan selengkapnya disajikan pada Tabel 4. Pada Tabel tersebut diketahui bahwa nilai RPS tertinggi diperoleh pada kelompok perlakuan pemberian vaksin sel utuh yaitu sebesar $68,00 \%$; selanjutnya diikuti oleh kelompok perlakuan pemberian vaksin biakan cair sebesar $53,37 \%$; vaksin supernatan tanpa penyaringan sebesar $32,00 \%$ dan vaksin supernatan dengan penyaringan sebesar $14,67 \%$.

Jika ada kematian yang terjadi secara akut selama 24 jam pasca vaksinasi maka mengindikasikan bahwa vaksin yang digunakan berpengaruh negatif terhadap ikan yang divaksin. Pada penelitian ini ternyata tidak ditemukan adanya kematian ikan uji selama 24 pasca vaksinasi sehingga vaksin aman untuk diaplikasikan pada ikan.

\section{HASIL DAN BAHASAN}

Fluktuasi nilai titer antibodi pada serum darah ikan uji yang sangat variatif tersebut merupakan konsekuensi dari teknik pengamatan yang dilakukan melalui pendekatan populasi atau pooling system. Pendekatan teknik ini didasarkan pada kenyataan bahwa ukuran ikan yang digunakan masih relatif kecil (10-15 g/ekor), sehingga untuk mendapatkan sejumlah volume serum darah yang cukup untuk keperluan analisis harus diperoleh dari beberapa ekor ikan uji pada masing-masing kelompok perlakuan. Kesulitan teknis lainnya 
Tabel 3. Nilai rataan sintasan (\%) ikan uji pada akhir proses uji tantang terhadap Streptococcus agalactiae-N14G yang diamati selama 21 hari (tiga minggu)

Table 3. The value of the average survival rate (\%) of fish at the end of challenge test against Streptococcus agalactiae-N14G which was observed for 21 days (three weeks)

\begin{tabular}{|c|c|c|c|c|}
\hline & \multirow{2}{*}{$\begin{array}{l}\text { Perlakuan } \\
\text { Treatments }\end{array}$} & \multicolumn{3}{|c|}{ Sintasan (Survival rate) (\%) } \\
\hline & & $\begin{array}{l}\text { Minggu ke-1 } \\
\text { Week } 1\end{array}$ & $\begin{array}{l}\text { Minggu ke-2 } \\
\text { Week } 2\end{array}$ & $\begin{array}{l}\text { Minggu ke-3 } \\
\text { Week } 3\end{array}$ \\
\hline A & Biakan cair (Broth vaccine) & $73.4^{\mathrm{b}}$ & $69.0^{\mathrm{b}}$ & $65.0^{\mathrm{b}}$ \\
\hline B & Sel utuh (Whole cell vaccine) & $87.0^{\mathrm{a}}$ & $87.0^{\mathrm{a}}$ & $76.0^{\mathrm{a}}$ \\
\hline C & $\begin{array}{l}\text { Supernatan tanpa penyaringan } \\
\text { Crude extra cellular product }\end{array}$ & $80.0^{\mathrm{a}}$ & $63.0^{\mathrm{b}}$ & $49.0^{c}$ \\
\hline D & $\begin{array}{l}\text { Supernatan dengan penyaringan } \\
\text { Pure extra cellular product }\end{array}$ & $71.2^{\mathrm{b}}$ & $63.0^{c}$ & $36.0^{d}$ \\
\hline $\mathrm{E}$ & $\begin{array}{l}\text { Kontrol positif dengan Phosphate Buffered Saline (PBS) } \\
\text { Positive control Phosphate Buffered Saline (PBS) }\end{array}$ & $45.0^{d}$ & $42.3^{d}$ & $25.0^{f}$ \\
\hline $\mathrm{F}$ & $\begin{array}{l}\text { Kontrol negatif, tanpa perlakuan } \\
\text { Negative control, without treatment }\end{array}$ & $62.3^{c}$ & $49.0^{d}$ & $34.0^{\mathrm{e}}$ \\
\hline
\end{tabular}

Keterangan (Remarks):

Angka yang diikuti superscript yang sama memberikan pengaruh yang tidak berbeda menurut uji Duncan pada taraf 5\% (The number in the same superscript are not significant different according to Duncan test)

Tabel 4. Nilai sintasan dan persentase relatif sintasan pemberian berbagai sediaan vaksin Streptococcus agalactiae-N14G terhadap populasi ikan uji

Table 4. The value of survival rate and relative percent survival after Streptococcus agalactiae-N14G vaccine application on fish population

\begin{tabular}{|c|c|c|c|}
\hline & $\begin{array}{l}\text { Perlakuan } \\
\text { Treatments }\end{array}$ & $\begin{array}{l}\text { Sintasan } \\
\text { Survival rate (\%) }\end{array}$ & RPS \\
\hline A & Biakan cair (Broth vaccine) & 65 & 53.37 \\
\hline B & Sel utuh (Whole cell vaccine) & 76 & 68 \\
\hline $\mathrm{C}$ & $\begin{array}{l}\text { Supernatan tanpa penyaringan } \\
\text { Crude extra cellular product }\end{array}$ & 49 & 32 \\
\hline $\mathrm{D}$ & $\begin{array}{l}\text { Supernatan dengan penyaringan } \\
\text { Pure extra cellular product }\end{array}$ & 36 & 14.67 \\
\hline $\mathrm{E}$ & $\begin{array}{l}\text { Kontrol positif dengan Phosphate Buffered Saline (PBS) } \\
\text { Positive control Phosphate Buffered Saline (PBS) }\end{array}$ & 25 & - \\
\hline $\mathrm{F}$ & $\begin{array}{l}\text { Kontrol negatif, tanpa pe rlakuan } \\
\text { Negative control, without treatment }\end{array}$ & 34 & - \\
\hline
\end{tabular}

yang terkait dengan proses pengambilan serum darah adalah sulit untuk menjamin bahwa ikan yang sudah diambil darahnya pada satu titik pengamatan, sudah pulih kembali dan layak untuk diambil darahnya pada periode pengamatan berikutnya.
Kematian ikan uji pada masing-masing kelompok perlakuan mulai terjadi 24 jam pasca pemberian infeksi buatan, dan rata-rata mortalitas tertinggi mulai terjadi pada hari ke-5 hingga hari ke-11. Nilai rata-rata mortalitas kumulatif yang berkisar antara $24 \%$ hingga $75 \%$ 
selama proses uji tantang yang berlangsung selama 21 hari mengindikasikan bahwa infeksi bakteri S. agalactiae pada ikan nila bersifat akut, dan hal ini sesuai dengan kesimpulan Taukhid \& Purwaningsih (2009) bahwa secara laboratoris, infeksi S. agalactiae pada ikan nila bersifat akut; sedangkan infeksi S. iniae lebih bersifat kronis.

Efikasi sediaan vaksin pada penelitian ini yang dievaluasi berdasarkan rata-rata nilai persentase sintasan pasca uji tantang yang diamati selama tiga minggu terhadap isolat bakteri homolog (S. agalactiae-N14G) menunjukkan bahwa sediaan vaksin sel utuh (B) memberikan nilai sintasan tertinggi (76,0\%), selanjutnya diikuti oleh sediaan vaksin biakan cair (A) $(65,0 \%)$, sediaan vaksin supernatan tanpa penyaringan (C) $(49,0 \%)$, dan sediaan vaksin dengan penyaringan (D) $(36,0 \%)$; sedangkan pada kelompok kontrol positif dan negatif, masing-masing sebesar $25,0 \%$ dan $34,0 \%$. Hasil yang relatif sama diperoleh oleh Pasnik et al. (2005) yang melakukan pengujian efikasi dan durasi protensi pemberian vaksin S. agalactiae terhadap ikan nila dalam bentuk sediaan sel utuh (formalin killed) dan sediaan extracellular product (ECP) diperoleh rata-rata nilai sintasan yang berbeda nyata antara kelompok ikan yang divaksin dibandingkan dengan kelompok kontrol. Perbedaan tersebut terjadi dari hasil uji tantang yang dilakukan secara seri pada hari ke-47, 90, dan 180 pasca vaksinasi yang diberikan melalui penyuntikan secara intra peritoneal. Rataan sintasan pada kelompok ikan kontrol sebesar 16\%, 16\%, dan $4 \%$ untuk masing-masing periode uji tantang. Sintasan pada kelompok ikan yang divaksin sebesar 67\%, 62\%, dan 49\%. Antibodi spesifik pada kelompok ikan yang divaksin masih terdeteksi hingga hari ke-180, sedangkan pada kelompok ikan kontrol tidak mengalami peningkatan hingga akhir penelitian.

Performa dari capaian yang diperoleh masing-masing jenis sediaan vaksin pada penelitian ini dapat dijelaskan sebagai berikut: pada sediaan vaksin sel utuh, unsur-unsur imunogenik yang dimiliki oleh bakteri tersebut masih relatif lengkap, dan tidak ada lagi unsur toksikan karena telah dilakukan pencucian. Pada jenis sediaan vaksin biakan cair, meskipun berisi unsur-unsur imunogenik yang terkandung dalam sel utuh dan supernatan; namun masih mengandung unsur toksikan yang sangat mungkin berlaku sebagai immunosupresif. Kondisi yang sama, terjadi pada jenis sediaan vaksin supernatan dengan penyaringan maupun tanpa penyaringan. Toksikan berasal dari ECP bakteri dan kandungan formalin. Tetapi penggunaan formalin dalam sediaan vaksin masih dapat diterima dengan catatan bahwa konsentrasinya tidak tinggi sehingga tidak toksik ketika diaplikasikan baik melalui suntik, perendaman maupun melalui pakan. Jung et al. (2001) melakukan penelitian mengenai residu formalin $37 \%$ pada urat daging ikan olive flounder (Paralichthys olivaceus) dan black rockfish (Sebastes schlegeli) setelah divaksin dengan cara perendaman. Residu formalin dalam urat daging dapat luruh hingga konsentrasi yang setara dengan normal (kontrol) setelah 72 jam, yaitu kandungan residu yang terdeteksi pada perlakuan $100 \mathrm{mg} / \mathrm{L}$ setelah 1, 24, 48, dan 72 jam berturut-turut adalah 0,$8 ; 0,7 ; 0,8 ; 0,9$ $\mu \mathrm{g} / \mathrm{g}$. Begitu juga dengan residu pada air pemeliharaan dengan perlakuan $25,50,100$, 150 , dan $200 \mathrm{mg} / \mathrm{L}$ yang akan luruh berturutturut dalam jangka waktu 2, 6, 8, 9, dan 10 hari ketika diaerasi, tanpa diganti air dan luruh dalam jangka waktu 7, 9, 11, 13, dan 19 hari tanpa aerasi dan tanpa ganti air.

Formaldehide yang dipakai untuk membuat bahan buffer formalin merupakan bahan kimia yang umum digunakan dalam proses inaktifasi sediaan vaksin. Fungsi formaldehide adalah untuk menstabilkan komponen protein atau untuk inaktifasi molekul toksin dari bakteri. Formaldehide bereaksi dengan grup asam amino lisin yang merupakan produk tidak stabil membentuk ikan metilen sehingga menjadi grup asam amino yang stabil, reaksi ini dapat terbentuk antar asam amino dengan molekul yang sama sehingga membentuk ikatan silang antar internal protein atau antara dua molekul yang sama sehingga membentuk ikatan silang antar internal protein atau antara dua molekul membentuk ikatan dimer (senyawa kimia yang terdiri atas dua molekul monomer yang identik dan terikat bersama-sama) (Sato et al., 1984).

Relative percentage survival (RPS) merupakan nilai persen relatif sintasan kelompok ikan yang divaksin dibandingkan dengan nilai parameter yang sama dari kelompok ikan kontrol. Ellis (1998) menyatakan bahwa vaksin ikan masuk kategori efektif apabila memiliki nilai RPS $850 \%$. Berdasarkan kriteria tersebut, maka ada dua jenis sediaan vaksin yang perlu dikembangkan untuk tujuan pencegahan penyakit Streptococcosis pada ikan nila, yaitu jenis vaksin sel utuh yang memiliki nilai RPS sebesar $68,00 \%$ dan jenis sediaan vaksin 
biakan cair yang memiliki nilai RPS sebesar $53,37 \%$.

\section{KESIMPULAN DAN SARAN}

\section{Kesimpulan}

Efikasi sediaan vaksin tertinggi diperoleh pada sediaan vaksin sel utuh (B) $(76,0 \%)$, selanjutnya diikuti oleh sediaan vaksin biakan cair (A) (65,0\%), sediaan vaksin supernatan tanpa penyaringan (C) $(49,0 \%)$, dan sediaan vaksin dengan penyaringan (D) (36,0\%); sedangkan pada kelompok kontrol positif dan negatif, masing-masing sebesar $25,0 \%$ dan $34,0 \%$.

Efektivitas vaksin yang didasarkan pada nilai RPS, diperoleh dua jenis vaksin kategori efektif, yaitu jenis vaksin sel utuh dengan nilai RPS sebesar 68,00\% dan jenis sediaan vaksin biakan cair dengan nilai RPS sebesar $53,37 \%$.

\section{Saran}

Perlu kajian yang lebih detail terhadap dosis efektif sediaan vaksin sel utuh dan biakan cair untuk dikembangkan hingga diperoleh produk biologi yang efektif, aplikatif, dan ekonomis dan perlu kajian tentang periode pembentukan dan peluruhan kadar antibodi protektif, sehingga dapat digunakan untuk menentukan perlu tidaknya vaksinasi ulang (booster) untuk memberi perlindungan total selama masa pemeliharaan ikan nila.

\section{UCAPAN TERIMA KASIH}

Penulis mengucapkan terima kepada Saudara Edy Farid, Ahmad Wahyudi, Mikdarullah, dan Bambang Priadi atas bantuannya selama pelaksanaan kegiatan riset. Riset ini dibiayai oleh DIPA 2010 Balai Penelitian dan Pengembangan Perikanan Budidaya Air Tawar, Bogor

\section{DAFTAR ACUAN}

Akhlaghi, M., Munday, B., \& Whittington, R. 1996. Comparison of passive and active immunization of fish against streptococcosis (enterococcosis). Journal of Fish Diseases, 19: 251-258.

Eldar, A., Shapiro, O., Bejerano, Y., \& Bercovier, H. 1995. Vaccination with whole-cell vaccine and bacterial protein extracts protects tilapia against Streptococcus difficile meningoencephalitis. Vaccine, 13: 867-870.

Eldar, A., Horovitcz, A., \& Bercovier, H. 1997. Development and efficacy of a vaccine against Streptococcus iniae infection in farmed rainbow trout. Veterinary Immunology and Immunopathology, 56: 175-183.

Ellis, A.E. 1998. Fish Vaccination. Academic Press Limited. London, 255 pp.

Evans, J.J., Klesius, P.H., Glibert, P.M., Shoemaker, C.A., Al Sarawi, M.A., Landsberg, J., Duremdez, R., Al Marzouk, A., \& Al Zenki, S. 2002. Characterization of beta-haemolytic Group B Streptococcus agalactiae in cultured seabream, Sparus auratus (L.) and wild mullet, Liza klunzingeri (Day), in Kuwait. Journal of Fish Diseases, 25: 505-513.

Evans, J.J., Klesius, P.H., \& Shoemaker, C.A. 2004a. Streptococcus agalactiae Vaccine. Invention Report No. 0170.03. ARS Subject Invention Serial\# 10/807,575. Filed March 18, 2004. Patent pending.

Evans, J.J., Klesius, P.H., Shoemaker, C.A., \& Fitzpatrick, B.T. 2004b. Streptococcus agalactiae vaccination and infection stress in Nile tilapia, Oreochromis niloticus. Journal of Applied Aquaculture, 22: 3,7693,773 .

Evans, J.J., Shoemaker, C.A., \& Klesius, P.H. 2004c. Efficacy of Streptococcus agalactiae (Group B) vaccine in tilapia (Oreochromis niloticus) by intraperitoneal and bath immersion administration. Vaccine, 22: 3,769-3,773.

Jung, S.H., Kim, J.W., Jeon, I.G., \& Lee, Y.H. 2001. Formaldehyde residues in formalin-treated olive flounder Paralichthys olifaceus, black rockfish Sebastes schlegeli and seawater. Aquaculture, 194: 253-262.

Klesius, P.H., Shoemaker, C.A., \& Evans, J.J. 2000. Efficacy of a killed Streptococcus iniae vaccine in tilapia (Oreochromis niloticus). Bull. Eur. Ass. Fish Pathol., 19(1): 38-41

Pasnik, D.J., Evans, J.J., Panangala, V.S., Klesius, P.H., Shelby, R.A., \& Shoemaker, C.A. 2005. Antigenicity of Streptococcus agalactiae extracellular products and vaccine efficacy. Journal of Fish Diseases, 28(4): 205212.

Plumb, J.A., Schachte, J.H., Gaines, J.L., Peltier, W., \& Carroll, B. 1975. Streptococcus sp. from marine fishes along the Alabama and Northwest Florida coast of the Gulf of Mexico. Transactions of the American Fisheries Society, 103: 358-361.

Sato, Y., Kimura, M., \& Fukumi, H. 1984. Development of a pertussis component vaccine in Japan. Lancetti, p. 122-126.

Taukhid \& Purwaningsih, U. 2009. Screening isolat, preparasi, dan viabilitas bakteri 
Streptococcus spp. sebagai kandidat antigen dalam pembuatan vaksin untuk pencegahan penyakit streptococciasis pada ikan nila, Oreochromis niloticus. Laporan
Teknis Riset Perikanan Budidaya Air Tawar. Balai Riset Perikanan Budidaya Air Tawar. (Tidak dipublikasi). 